ENCYCLOPEDDE Encyclopédie berbère

BERBERE

3 | 1986

3 | Ahaggar - Alī ben Ghaniya

\title{
'Alī Ben Yūsuf ben Tašfin
}

L. Golvin

\section{OpenEdition}

Journals

Édition électronique

URL : http://journals.openedition.org/encyclopedieberbere/2412

DOI : 10.4000/encyclopedieberbere.2412

ISSN : 2262-7197

\section{Éditeur}

Peeters Publishers

\section{Édition imprimée}

Date de publication : 1 juillet 1986

Pagination : 444-445

ISBN : 2-85744-260-2

ISSN : 1015-7344

\section{Référence électronique}

L. Golvin, « 'Alī Ben Yūsuf ben Tašfin », Encyclopédie berbère [En ligne], 3 | 1986, document A161, mis en ligne le 01 décembre 2012, consulté le 21 octobre 2020. URL : http://journals.openedition.org/ encyclopedieberbere/2412; DOI : https://doi.org/10.4000/encyclopedieberbere.2412

Ce document a été généré automatiquement le 21 octobre 2020

(C) Tous droits réservés 


\title{
'Alī Ben Yūsuf ben Tašfin
}

\author{
L. Golvin
}

1 Abū'l-Ḥasan 'Alī b.Yūsuf b. Tašfīn al-Lamtūnī, second souverain de la dynastie des Almoravides né à Ceuta, avait vingt-trois ans lorsque mourut son père, Yūsuf $b$. Tašfín, fondateur de la dynastie. Ce dernier lui léguait un empire en pleine expansion dont l'autorité s'étendait de l'Andalousie au Maghrib central. De mère chrétienne, 'Alī s'était préparé à son rôle de chef en Andalousie auprès des meilleurs maîtres de l'époque, c'est dire qu'il n'avait ni la rudesse de son père, ni les qualités d'endurance physique acquises par ses aïeux au Sahara.

2 C'est à Marrakech qu'il reçoit le serment d'allégeance, le $1^{\mathrm{er}}$ muharram $500 / 2$ septembre 1106, et c'est là qu'il résidera le plus longtemps, faisant de la cité fondée par son père, la brillante capitale du Maghrib al-Aqșā, rivale de Fès où le nouveau chef ne se sent pas à l'aise.

3 En dépit d'une tentative d'insurrection d'un neveu de 'Alī un moment maître de Fès, cité qui avait refusé, avec ce prétendant, le serment d'allégeance (Ibn Haldūn), le règne commence bien. Le rebelle est rapidement mis hors d'état de nuire et Fès mise au pas en rabi' II 500 / 6 décembre 1106. Immédiatement, 'Alī se rend en Espagne pour y recevoir l'hommage des chefs andalous; il en profite pour destituer quelques gouverneurs et installer à leur place des hommes à lui. Son propre frère, Tamīm, est nommé gouverneur de l'Andalousie avec résidence à Grenade. A ce titre, il remporte quelques succès sur les Chrétiens, notamment à Uclès (502 / 1108-9), il écrase même l'armée d'Alphonse VI commandée par son fils Sancho. Peu de temps après, en 503 / 1109, 'Alī prend lui-même le commandement des troupes et pousse en direction de Tolède qu'il n'atteindra pas. Ce succès assure cependant son autorité, vers 504 / 1110, les Chrétiens sont partout sur la défensive et les derniers petits dynastes qui subsistent (Saragosse et les Baléares) disparaissent. L'unité du Blad al-Andalus est réalisée.

Deux fois encore, 'Alī devait franchir le détroit pour mettre un frein aux entreprises chrétiennes. La plus importante de ces offensives, conduite par Alphonse le Batailleur, avait amené les Aragonais au cœur de l'Andalousie, puis aux portes de Cordoue, elle avait même atteint les rives de la Méditerranée. Pourtant, les armées almoravides, malmenées mais non écrasées, ne ralentissaient pas leur action de harcellement. Les 
difficultés internes en Aragon aussi bien qu'en Castille devaient permettre aux Musulmans de rétablir provisoirement la situation; toutefois, 'Alī ne s'aventurait plus au delà de Cordoue et une de ses dernières victoires fut remportée à Fraga (Province de Lérida) 23 ramadan 528 / 17 juillet 1134.

5 A cette date, le souverain se trouvait menacé sur son propre territoire, aux portes mêmes de Marrakech où l'action du Mahdī Ibn Tumart avait mobilisé la montagne berbère autour des Masmuda. Le chef berbère s'était installé en 1125 à Tinmāl et, solidement retranché, il y préparait méthodiquement les succès futurs des Almohades.

Replié á Marrakech où il compte devantage, semble-t-il, sur ses mercenaires chrétiens venus d'Espagne que sur ses troupes, le souverain, très dévôt, a laissé les rènes $d u$ pouvoir aux fuqahā. Il est cependant loin de s'adonner à une vie d'ascèse. Il vit dans un magnifique palais richement décoré, au milieu de son harem, dans un luxe que son père aurait bien certainement condamné. Lettré (l'arabe est devenu langue officielle alors que son père ne parlait que le berbère) il s'entoure de savants; sa cour est brillante, mais, lorsqu'il meurt, le 8 rağab 537 / 28 janvier 1143, il lègue à son fils Tašfin un trône chancelant que ce dernier ne saura pas défendre.

7 Au demeurant, le second des Emirs almoravides n'avait ni l'autorité ni les qualités de son père. Plus andalou que maghrébin, il transpose sur le territoire africain le charme des petites cours andalouses; les grandes chevauchées épiques ne le passionnent pas.

C'est à lui pourtant que Marrakech doit ses lettres de noblesse. Il transforme le campement encore tout saharien de Yūsuf en une cité digne de celles d'Espagne après d'ingénieux travaux d'hydraulique. Il construit les murailles d'une Qașba et y fait élever un magnifique palais avec de beaux jardins en riyāḍ il fait édifier une grande mosquée. Malheureusement pour nous, ces constructions seront systématiquement ruinées par les Almohades à l'exception d'un petit pavillon dont la beauté est saisissante (Qubba barudiyyîn). A Tlemcen, le souverain fait construire la remarquable grande mosquée, joyau de l'art musulman. A Fès, il dote la Qarawiyyīn (qu'il agrandira considérablement) d'un somptueux décor. Partout, il construit, il embellit, il encourage les lettres et les sciences.

En résumé, la règne de 'Alī ne manque pas de grandeur, mais il portait en lui d'étonnantes faiblesses qui seront fatales à la dynastie.

\section{BIBLIOGRAPHIE}

IBN IDĀRĪ Bayān, éd. Lévi-Provençal, Beyrouth 1929 ; éd. G.S. Colin et Lévi-

Provençal, 2 vol., Beyrouth, 1948 ; éd. Iḥsān ‘Abbās, 1 vol. Beyrouth 1965

IBN KALDŪN Histoire des Berbères, t. II.

IBN ḤALLIKĀN. Wafayat.

IBN ḤALLIKĀ. Al-Hulat et Al-Iḥāṭa. 
IBN AL ATĪR. Kāmil.

AL-NUWAYRĪ. Historia; ed. Gaspar Remiro.

IBN AL-QATTṬĀN. Naz al-Djumān,

LEVI-PROVENÇAL. Documents inédits d'histoire almoravide et Documents inédits d'histoire almohade, Paris, 1928.

‘ABD AL-WĀHID AL-MARRAKUŠĨ. Al-Hhulal al-Mawšiyya.

CODERA. Decadencia y desaparición de los Almoravides en España, Saragosse, 1899.

TERRASSE H. Histoire du Maroc, Casablanca, 1949.

MARÇAIS G. La Berbérie musulmane et l'Orient au Moyen Age, Paris, 1946.

DEVERDUN G. Marrakech, Rabat 1959.

INDEX

Mots-clés : Biographie, Espagne, Géographie, Maroc, Moyen Âge 